\title{
Paratuberculosis or avian tuberculosis in red deer with chronic diarrhea?*
}

\author{
Paratuberculosis o tuberculosis aviar en ciervo rojo con diarrea crónica?
}

\author{
M Pradenas ${ }^{\mathrm{a}}$, MJ Navarrete-Talloni ${ }^{\mathrm{a}}$, M Salgado ${ }^{\mathrm{b}}$, P Zamorano ${ }^{\mathrm{b}}$, E Paredes $^{\mathrm{a}^{*}}$ \\ ${ }^{a}$ Animal Pathology Institute, Faculty of Veterinary Science.

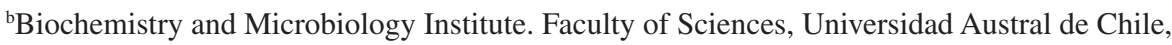 \\ Campus Isla Teja. P.O. Box 567, Valdivia, Chile.
}

\begin{abstract}
SUMMARY
Mycobacterium avium subsp. paratuberculosis (Map) is the etiological agent of paratuberculosis. In Chile, information about Map isolation from both domestic ruminant and wildlife species has been accumulating, but it has extended to other species. In Chile, deer farming activity has been focused in hunting and meat production. No paratuberculosis surveillance has been reported for these source herds. In the present study, chronic diarrhea and poor body condition in some animals belonging to a deer farm was informed. Four adult affected hinds were euthanized under suspicion of paratuberculosis. In all animals macroscopic and microscopic lesions consistent with paratuberculosis were observed. Map-positive culture results from faecal and tissue samples, complemented with positive-PCR-results from fixed tissues are informed. Evidence has been found on cattle and deer populations being connected since molecular characterization of the Map isolated from deer lack of variation between the cattle control strain. The latter could indicate that both species share the same bacteria, suggesting there is interspecies transmission. Complementary diagnostic methods were accurate to diagnose paratuberculosis and to differentiate the clinical deer case from other mycobacterial infection. The epidemiological findings suggest that the infection in the deer farm could be transmitted from a cattle herd, making this the first reported case of paratuberculosis in deer farm in Chile.
\end{abstract}

Key words: deer, histopathology, paratuberculosis, PCR.

\section{RESUMEN}

\begin{abstract}
Mycobacterium avium subsp. paratuberculosis (Map) es el agente etiológico de la patuberculosis. En Chile, antecedentes del aislamiento de Map tanto en rumiantes domésticos como en especies de vida silvestre se han ido acumulando a través del tiempo, sin embargo, esto tiene que estar afectando también a otras especies. En Chile, la crianza de ciervos se ha focalizado en dos objetivos: cotos de caza y producción de carnes exóticas, no existiendo un programa de vigilancia ni siendo reportada esta enfermedad en rebaños de este tipo. Este trabajo reporta la presencia de diarrea crónica y pobre condición corporal en algunos animales pertenecientes a una granja de ciervos donde se sospechó la presencia de paratuberculosis. Cuatro ciervos adultos fueron eutanaziados bajo esta sospecha. Todos los animales presentaron lesiones macro y microscópicas compatibles con paratuberculosis. Resultados positivos al cultivo bacteriológico a partir de heces y muestras de tejido, además de PCR a partir de tejido fijado evidencian la infección. De acuerdo a los resultados de caracterización molecular de las cepas aisladas de los ciervos que no muestran variación entre cepas control de bovino, se evidencia que ambas poblaciones estarían conectadas. Complementariamente, los métodos diagnósticos utilizados fueron muy precisos para diagnosticar paratuberculosis y para diferenciar casos clínicos en ciervos de otras micobacteriosis. Las características epidemiológicas descritas en este estudio sugieren que la infección presente en la granja de ciervos, pudo tener su origen en un rebaño bovino. Finalmente, los hallazgos anteriormente mencionados representan el primer reporte de paratuberculosis en ciervos de granja en Chile.
\end{abstract}

Palabras clave: ciervos, histopatología, paratuberculosis, PCR.

\section{INTRODUCTION}

Paratuberculosis is a chronic wasting enteritis of ruminants caused by Mycobacterium avium subsp. paratuberculosis (Map). The disease is characterised by granulomatous enteritis, diarrhea, loss of body weight and death. It can be found worldwide and mainly affects domestic ruminants, being responsible for significant eco-

Accepted: 22.08.2013.

\# This study was supported by the project DID S-2011-04, Dirección de Investigación y Desarrollo, Universidad Austral de Chile. P.O. Box 567, Valdivia, Chile; eparedes@uach.cl nomic losses of livestock production (Lombard 2011). In addition, some authors consider Map to be a potential zoonotic agent, as it has been associated with Crohn's disease in humans (Chiodini et al 2012).

In Chile, Map infection has been reported in cattle (Grinbergs and Caorsi 1958), sheep (Zamora et al 1975), goats (Kruze et al 2006), guanacos (Lama guanicoe) (Salgado et al 2009) and hares (Salgado et al 2011 b). Due to the close relation between wild and domestic animals in some areas, it is suggested that other wild and captive animal populations could be infected (Salgado et al 2011'a)

Infection by Map has also been described in wild and captive deer populations in many countries (de Lisle et al 
1993, Power et al 1993, Fawcett et al 1995, Manning et al 1998, Godfroid et al 2000, Paolicchi et al 2001, Alvarez et al 2005, Machackova-Kopecna et al 2005, van Kooten et al 2006, Mackintosh et al 2007). Since 1980, paratuberculosis has been an emergent problem in deer farming with important underestimated losses, mainly due to outbreaks of the clinical disease (Mackintosh et al 2002).

In Chile there are approximately 6,000 introduced deer largely distributed in the Southern regions (INE $2007^{1}$ ). Most animals have been imported from Argentina, New Zealand and Europe (Paolicchi et al 2001, Marco et al 2002, de Lisle et al 2003, Mackintosh et al 2004), where paratuberculosis have been reported in deer in high prevalence (Mereb et al 1994, de Lisle et al 2003) and are used for hunting and meat production.

In deer, as in cattle, sheep and goats, paratuberculosis produces a long term enteritis that finally leads to loss of body condition and death in severely affected animals (Machackova-Kopecna et al 2005). Paratuberculosis diagnosis in deer is based on Map detection in faeces, postmortem and histopathological examination of tissues (specially the lower part of the jejunum, ileum, ileocecal valve and its associated lymph nodes) (Clarke 1997). Histopathological assessment includes different grading systems and disease classification, such as paucibacillary and multibacillary, already described for several species with paratuberculosis (Carrigan and Seaman 1990, Clarke and Little 1996, Perez et al 1996, Gonzalez et al 2005, Balseiro et al 2008, Clark et al 2010). However, the histopathological observation of lesions is insufficient to confirm the disease, especially due to the similarity of lesions caused by Map and M. avium subsp. avium (Maa). Co-infection with Map and Maa, which causes clinical disease and eventually death, complicates and challenges the bacteriological diagnosis of mycobacterial infections in deer (Godfroid et al 2005). Besides, just as in the case of avian tuberculosis, lesions found at slaughter in deer subclinically infected with paratuberculosis may cause problems because of their gross and histopathological similarity to lesions of tuberculosis (Campbell 1995).

The aim of the present study was to confirm Map infection and differentiate a clinical case from other mycobacterial infections, in farmed deer of Southern Chile.

\section{MATERIAL AND METHODS}

\section{ANIMAL POPULATION}

Animals belonged to a hunting and breeding deer farm located in the Región de Los Lagos, Southern Chile. The herd was comprised of 180 red deer (Cervus elaphus) and 200 fallow deer (Dama dama). An interesting epidemiological feature was that the pastures used for the deer had been previously used to raise dairy cattle

INE, Instituto Nacional de Estadísticas Chile. www.ine.cl with an estimated individual prevalence of $15 \%$, with 3-5 clinical cases per year. This herd was comprised of 800 cattle grazing about 700 hectares and it was located in close proximity to the deer herd.

\section{ANIMAL SAMPLING}

Four adult hinds, with evident poor body condition, showed liquid and greenish diarrhea (without blood or fibrin) and faeces adhered to their tail and hocks. Paratuberculosis was suspected and the animals were humanely euthanized.

\section{NECROPSY AND SAMPLES}

Complete necropsy was performed on each animal and gross lesions were recorded focusing on intestine, lymph nodes and liver. Samples were taken for histopathology, bacteriological culture and PCR. Different sections of small and large intestine, lymph nodes, liver, abomasum, heart, spleen, kidneys and lungs were removed and fixed in $10 \%$ buffered formalin for histopatho$\log y$.

\section{HISTOPATHOLOGY}

Sections of $5 \mathrm{~mm}$ were stained with Hematoxilin and Eosin (HE) and Ziehl Neelsen (ZN) (at least 3 sections per organ). Lesions were described and graded from 0 to 3 regarding cellular infiltration (Carrigan and Seaman 1990). Also, samples were graded from 0 to 3 depending on the amount of acid fast bacteria (AFB) observed in the tissues, and then classified as multibacillary or paucibacillary (Clarke and Little 1996).

\section{BACTERIOLOGY}

Bacterial cultures. Faecal and tissue samples (ileum and ileocecal lymph node) were used. Two grams of each sample were homogenised and decontaminated with hexadecilpiridinium (HPC) $0.9 \%$ overnight, and were centrifuged at $3500 \mathrm{x} \mathrm{g}$ for $20 \mathrm{~min}$. Pellets were suspended in $1 \mathrm{~mL}$ of antibiotic solution (vancomicyn $100 \mathrm{mg} / \mathrm{ml}$, nalidixic acid $100 \mathrm{mg} / \mathrm{ml}$ and amphotericim B $50 \mathrm{mg} / \mathrm{ml}$ ) overnight and an aliquot of $150 \mathrm{ml}$ was inoculated in four slants of Herrold's medium (HEYM), three with mycobactin J and one without it. Cultures were incubated at $37^{\circ} \mathrm{C}$ up to 5 months. All mycobactin-dependant colonies resembling Map were submitted to molecular confirmation.

\section{DNA EXTRACTION-PURIFICATION}

Real-time IS900 PCR using the ROCHE system (Roche, Indianapolis, IN) as described previously (Salgado et al 2011 ${ }^{\mathrm{b}}$ ) was used. The ROCHE system reports crossing-point $(\mathrm{Cp})$ values. 


\section{MOLECULAR CONFIRMATION}

The Real-time PCR system consisted in a multiplex PCR, where the targets were the insertion elements IS900 and IS901 sequences of Map and Maa, respectively. The primers and probes were designed with the ProbeFinder program version 2.45 (ROCHE). The PCR mix for each reaction consisted of $9.5 \mu \mathrm{l}$ water (Sigma-Aldrich), $0.5 \mu \mathrm{l}$ (1 $\mu \mathrm{M})$ probe, $0.5 \mu \mathrm{l}(2 \mu \mathrm{M})$ of each primer (sense and antisense) and $4 \mu$ LightCycler ${ }^{\circledR}$ TaqMan ${ }^{\circledR}$ Master kit. Five microliters of the DNA template were added to the mix. The reactions were run in the LightCycler 2.0 ROCHE system under the following standard conditions: one cycle to $95^{\circ} \mathrm{C}$ for $10 \mathrm{~min}$ and 45 cycles with two steps of $95^{\circ} \mathrm{C}$ for $10 \mathrm{~s}$, $60^{\circ} \mathrm{C}$ for $30 \mathrm{~s}$ and $72^{\circ} \mathrm{C}$ for $1 \mathrm{~s}$. and cooling was at $40^{\circ} \mathrm{C}$ for 30 s. Negative and positive DNA controls (Mycobacterium avium subsp. paratuberculosis ATCC 19698 and Mycobacterium avium subsp. avium ATCC 4440) were included.

\section{TYPING}

To distinguish subtypes of Map, deer isolates were assayed by IS1311 PCR-REA at the Biochemistry and Microbiology Department, Universidad Austral de Chile according to the protocol described by (Marsh et al 1999). The previously described primers M56 (59- GCGTGAGGCTCTGTGGTGAA-39) and M94 (59-CAGCGATCGTCGACAGTGTG-39) were used to amplify a region of the IS1311 insertion sequence (Whittington et al 1998, Marsh et al 1999). Briefly, a reaction volume of $50 \mathrm{ml}$ containing $5 \mathrm{ml}$ of the DNA sample, $4 \mathrm{ml}$ of each primer $(10 \mathrm{pmol} /$ $\mathrm{ml}), 22.6 \mathrm{ml}$ of water, $4 \mathrm{ml} \mathrm{dNTPs}(10 \mathrm{mM}), 5 \mathrm{ml} \mathrm{MgCl} 2$ (25 mM), $5 \mathrm{ml}$ PCR buffer II (103), and $0.4 \mathrm{ml}$ Taq Gold polymerase $(5 \mathrm{U} / \mathrm{ml})$ was used. The PCR procedure was performed under the following conditions: one cycle of denaturation at $94{ }^{\circ} \mathrm{C}$ for $3 \mathrm{~min}$ followed by 37 cycles of denaturation at $94{ }^{\circ} \mathrm{C}$ for $30 \mathrm{sec}$, annealing at $62{ }^{\circ} \mathrm{C}$ for 15 sec, and extension at $72{ }^{\circ} \mathrm{C}$ for $1 \mathrm{~min}$. Polymerase chain reaction results were assessed by electrophoresis in $2 \%$ agarose gels stained with ethidium bromide. The IS1311 PCR products were gel-purified using the Qiaquick Gel extraction kit (Qiagen GMBH, Hilden, Germany). Restriction endonuclease analysis was prepared by adding $4-12 \mathrm{ml}$ of purified PCR product, 2 U of HinfI restriction endonuclease (Promega Corp., Madison, Wisconsin, USA), $1.6 \mathrm{ml}$ of buffer (supplied with restriction endonuclease), and made up to $16 \mathrm{ml}$ with sterile purified water. Restriction digests were incubated for $2 \mathrm{hr}$ at $37 \mathrm{C}$ and were assessed by electrophoresis in $4 \%$ agarose gels stained with ethidium bromide.

To complement the typing information and to obtain more discriminatory power, DNA extracts from the subset of Map isolates run in REA-PCR, and confirmed by IS900 real-time PCR, were subjected to MIRU-VNTR typing. MIRU-VTNR typing was performed using 5 loci identified as polymorphic for Map K10 and called MIRU-VNTR 292, X3, 25, 47 and 3 (from locus 1 to locus 5) (Thibault et al 2007). Primers designed to target flanking regions of the MIRU-VNTRs and the conditions of the PCR amplification was carried out as described by Thibault et al (2007). Briefly, PCR mixture for each MIRU-VNTR locus comprised $5 \mu \mathrm{l}$ of template DNA, $1.5 \mathrm{mM}$ of magnesium chloride, $1 \mu \mathrm{l}$ of dimethyl sulfoxide (Sigma, St. Louis, Mo) (except for locus 2), $1 \mu \mathrm{M}$ of each primer, $50 \mu \mathrm{M}$ of dATP, $\mathrm{dCTP}, \mathrm{dGTP}$, and dTTP and 1.25 U of Platinum Taq (Invitrogen Ltd., Paisley, UK) in a final volume of $25 \mu$ l. Reactions were carried out using a GeneAmp 9600 PCR system (Applied Biosystems, Foster City, CA, USA). PCR conditions were as follows: 1 cycle of $5 \mathrm{~min}$ at $94^{\circ} \mathrm{C}, 30$ cycles of $30 \mathrm{~s}$ at $94^{\circ} \mathrm{C}, 30 \mathrm{~s}$ at $58^{\circ} \mathrm{C}$, and $30 \mathrm{~s}$ at $72^{\circ} \mathrm{C}$, and $1 \mathrm{cycle}$ of $7 \mathrm{~min}$ at $72^{\circ} \mathrm{C}$. To detect differences in repeat numbers, the PCR products were analyzed by electrophoresis using $1.5 \%$ agarose gels. Repeat numbers (alleles) were determined according to amplified fragment sizes using Gel Doc 2000 (Biorad, Herefordshire, UK) and Quantity One 4.2.1.software (Biorad) for fragment size calculation.

\section{FIXED TISSUE CONFIRMATION PRESENCE/ABSENCE OF MAP AND $M A A$}

After histopathological and bacteriological results, paraffin blocks of the four animals containing intestine, liver and lymph nodes were selected for Real Time PCR, in order to confirm or discard coinfection of Map and Maa. To prevent cross contamination on the samples for PCR, the microtome and each paraffin block were disinfected with a chlorine solution $10 \%$ and then with ethanol $100 \%$ between cuts and before inserting a new one into the microtome. Two $5 \mathrm{~mm}$ sections were cut and transferred to a sterile $1.5 \mathrm{~mL}$ tube for paraffin removal, as described by Miller et al (1997). After the deparafinization process of the paraffin-embedded specimen, the samples were subjected to the above explained protocols for DNA extraction and Real-Time PCR confirmation.

\section{RESULTS}

\section{NECROPSY}

Poor body condition and greenish diarrhea was observed externally in all animals (figure 1A). As a first approach, the intestinal wall was thickened and firm. The intestinal mucosa was corrugated and proliferative. Additionally, enlarged mesenteric lymph nodes and dilation of mesenteric lymphatic vessels was observed in all animals (figure 1B). Furthermore, mesenteric lymphatic vessel calcification was evident in two animals (figure 1C). There were no other organs with macroscopic lesions.

\section{HISTOPATHOLOGY}

Two animals presented the multibacillary form of disease and the other two presented the paucibacillary form. 


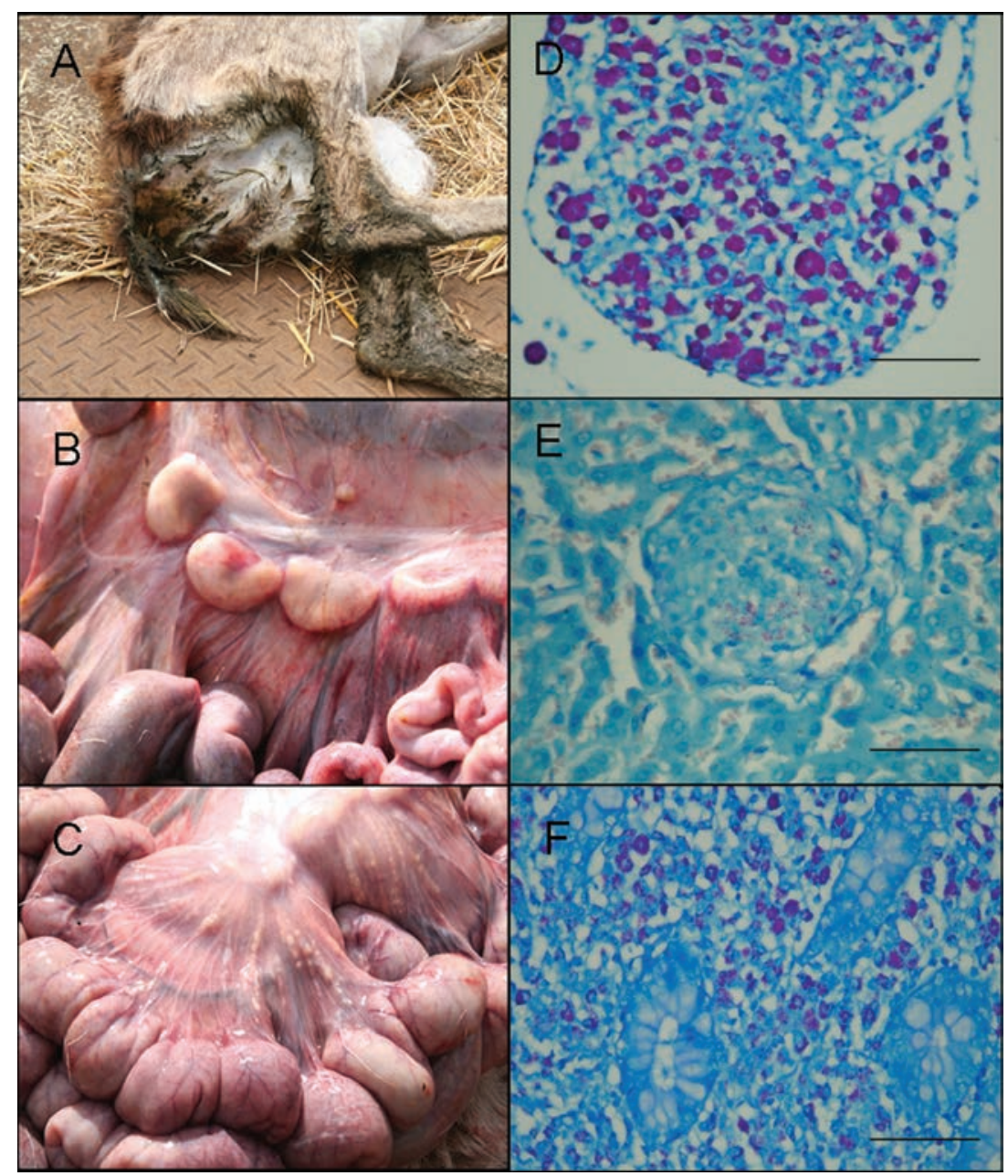

Figure 1. Poor body condition and greenish diarrhea (A), Enlarged and activation of mesenteric lymph nodes (B), Calcification of the mesenteric lymphatic vessels (C), Intense macrophage infiltration with many acid-fast bacteria in the ileum mucosa (D), Granuloma with acid-fast bacteria in liver (E), Diffuse macrophage infiltrate in caecum with acid fast bacteria in corion (F) (Ziehl-Neelsen. 40X. Bar $=100 \mu \mathrm{m}$.)

Mala condición corporal y diarrea verdosa (A), Nódulos linfáticos mesentéricos aumentados de tamaño y activos (B), Calcificación de vasos linfáticos mesentéricos (C), Mucosa del ileon con intenso infiltrado macrofágico con múltiples bacterias ácido alcohol resistentes (D). Granuloma hepático con bacterias ácido alcohol resistentes (E), Ciego con infiltado macrofágico difuso y bacterias ácido alcohol resistentes en corion (F). (ZiehlNeelsen. 40X. Bar $=100 \mu \mathrm{m}$.)

In the multibacillary form, Langhan's giant cells were observed containing numerous AFB. Paucibacillary lesions tended to an increased numbers of giant cells and smaller macrophages rather than the multibacillary form. Paucibacillary forms of the disease were more evident in deer with mild disease, while multibacillary forms were more evident in deer with the severe lesions. Ileum was the intestinal segment that was mostly affected in both forms.

In the multibacillary form, one case showed ileum with severe diffuse histiocytic infiltration in the lamina propria (graded 3) with abundant AFB (graded 3) (figure 1D). In the submucosal layer, small amounts of AFB were observed, including mild macrophage inflammatory infiltrate. The serosa of this portion presented moderate histiocytic infiltration with a moderate amount of AFB associated to blood and lymphatic vessels (graded 2). In the mesenteric lymph nodes, multifocal granulomas and diffuse histiocytic infiltration with giant cells (graded 3) and necrosis were observed; lymphoid follicles and medullar sinuses were invaded with mononuclear inflammatory infiltrate. Moderate amounts of AFB were associated with macrophages and giant cells (graded 2). In liver, multifocal granulomas (figure 1E) and focal macrophagical inflammatory infiltrate were observed (graded 2). Perivascular macrophagical infiltration was also associated with the periportal area, with moderate AFB (graded 2). Some focal necrotic areas were present, surrounded by histiocytic infiltration without AFB.

Also, in the multibacillary form the large intestine was affected. Caecum presented mononuclear infiltration 
and abundant macrophages in the corion (graded 3) and abundant AFB (graded 3) (figure 1F). In the submucosal layer, infiltration was moderate and mild dilatation of lymphatic vessels was observed. Acid fast bacteria were present inside the macrophages (graded 1). Deeper layers, such as muscularis and serosa, besides the related connective tissue, were also affected with inflammatory mononuclear infiltration (grading 2). In the serosa, AFB were associated with perivascular areas (graded 1). There were no lesions or AFB observed in abomasum, heart, spleen, kidneys and lungs (graded 0 ).

In the two paucibacillary cases, mixed inflammatory infiltrate in ileum was present (grade 3), and lymphoid activation besides eosinofilic infiltratation in medullar sinuses of lymph nodes was observed (grade 2). No AFB was observed in ileum, mesenteric lymph nodes or in the hepatic lymph nodes. However, in one animal mild histiocytic infiltration and small granuloma with few AFB (grade 1) were present in liver. The main lesion in this case was a moderate mononuclear infiltration with macrophages in ileum and periportal fibrosis in liver (graded 2). Results are summarized in table 1.

Incidental findings, such as eosinophilic infiltration in ileum and mesenteric lymph node with abscess, were observed. Protozoa as coccidia in ileum and sarcosporidium in heart were present.

\section{CULTURE}

Overall, from just two animals Map isolation (ileum, lymph nodes and faeces) was informed, although all animals showed gross lesions consistent with paratuberculosis.

\section{MOLECULAR TYPING}

All colonies resembling Map molecularly characterised by REA-PCR were positive for IS1311 and corresponded to the cattle type (C-type) strain (figure 2)

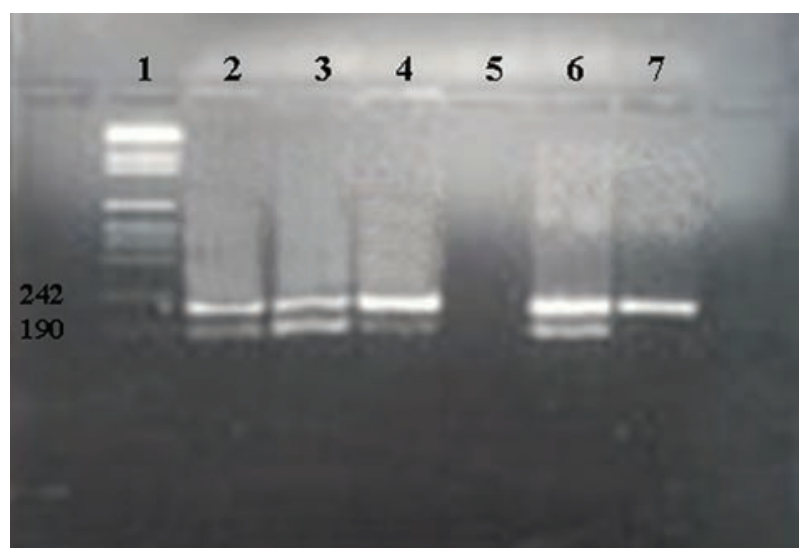

Figure 2. IS1311 polymerase chain reaction-restriction endonuclease analysis electrophoresis with HinfI (PCR-REA) on 2\% agarose gel. Lane 1: Kb DNA size marker. Lane 2 and 3: $\mathrm{C}$ type pattern from deer isolates obtained in the present study. Lane 4: and 6: $\mathrm{C}$ type cattle strain and lane 7 shows an $\mathrm{S}$ pattern from a chilean ovine isolate.

Reacción de polimerasa en cadena IS3111 y análisis de endonucleasa de restricción con HinfI (PCR-REA) en gel de agarosa al 2\% . Línea 1: Marcador de peso molecular. Línea 2 y 3: Patron tipo C provenientes de cepa aislada de uno de los ciervos del presente estudio. Línea 4 y 6: Patrón tipo $\mathrm{C}$ proveniente de una cepa aislada de bovino y Línea 7 muestra un patrón tipo $S$ provenientes de una cepa aislada de un ovino chileno.

Table 1. Performed tests in four hinds with clinical signs and lesions resembling paratuberculosis.

Pruebas realizadas en los 4 ciervos con signos clínicos y lesiones compatibles con paratuberculosis.

\begin{tabular}{|c|c|c|c|c|c|c|c|c|c|c|c|c|c|c|c|c|c|}
\hline \multirow[b]{3}{*}{ Test } & & \multicolumn{16}{|c|}{ Animals } \\
\hline & & \multicolumn{4}{|c|}{1} & \multicolumn{4}{|c|}{2} & \multicolumn{4}{|c|}{3} & \multicolumn{4}{|c|}{4} \\
\hline & & SI & LI & MLN & Liver & SI & LI & MLN & Liver & SI & LI & MNL & Liver & SI & LI & MNL & Liver \\
\hline Culture & HEYM & + & $\mathrm{np}$ & + & $\mathrm{np}$ & - & np & - & $\mathrm{np}$ & + & $\mathrm{np}$ & + & $\mathrm{np}$ & - & $\mathrm{np}$ & - & $\mathrm{np}$ \\
\hline \multirow{2}{*}{ Histopathology } & $\mathrm{H} \& \mathrm{E} / *$ & 3 & 3 & 3 & 2 & 3 & 0 & 2 & 0 & 3 & 3 & 3 & 2 & 3 & 0 & 2 & 1 \\
\hline & ZN/AFB & 3 & 3 & 2 & 2 & 0 & 0 & 0 & 0 & 3 & 3 & 2 & 2 & 0 & 0 & 0 & 1 \\
\hline \multirow{2}{*}{ Real Time PCR } & $\begin{array}{c}\text { Map } \\
(I S 900)\end{array}$ & + & + & + & + & + & + & + & + & + & + & + & + & + & + & + & + \\
\hline & $\begin{array}{c}M a a \\
(I S 901)\end{array}$ & - & - & - & - & - & - & - & - & - & - & - & - & - & - & - & - \\
\hline
\end{tabular}

SI: Small Intestine, LI: Large Intestine, MLN: Mesenteric Lymph Node, np: not performed

$H \& E^{*}$ grade of inflammation 
The two isolates tested belonged to the same MIRUVNTR type, and showed 4 repeats for TR292 (locus1) in contrast to the 3 repeats typical of the reference strain K10 (table 1). The number of repeats found in the remaining loci was identical to that of K10 strain (table 2).

\section{FIXED TISSUE CONFIRMATION PRESENCE/ABS- ENCE OF MAP AND $M A A$}

Animals with lesions but culture negative were suspected of Maa infection. Four animals were retested by Real Time PCR on fixed tissue to confirm or discard Map and Maa co-infection, all of them were PCR positive to Map and negative to Maa (table 2).

\section{DISCUSSION}

Due to similarities in the clinical signs and histopathology of the infection produced by Maa and Map (Mackintosh et al 1997, Mackintosh et al 2004), a diagnostic strategy was proposed in the present study to troubleshoot it. First of all, clinical signs and lesions observed in deer with the multibacillary form of the disease match the lesion descriptions for cattle and small ruminants in multibacillary cases (Buergelt et al 1978, Clarke 1997, Huda and Jensen 2003, Gonzalez et al 2005, Mackintosh et al 2007). However, lesions in the large intestine with diffuse inflammatory infiltration and AFB was observed as well as multifocal granulomas in liver, probably due to more susceptibility of the deer or may be a more pathogenic Map strain. The present study showed that in the multibacillary cases there were multifocal disseminated liver granulomas, with moderated intracellular AFB in the macrophages. This feature is commonly described in paratuberculosis cases in deer, but with scarce mycobacteria inside the macrophages (Del Pozo et al 2013). In the paucibacillary cases, neither hepatic lesions nor AFB were observed, probably due to the small amount of mycobacterium which remained in small intestine or lymph nodes, failing to reach the liver. On the other hand, in the study cases diffuse inflammatory infiltration in ileum was observed, instead of multifocal granulomas, which has been the main lesion described due to Map infection in deer (Mackintosh et al 2004, Mackintosh et al 2007, Balseiro et al 2008, Clark et al 2010). The latter may be due to the participation of several factors that could influence the immune response such as stage of infection, immunological status, age, animal susceptibility, infecting strain or breed (de Lisle et al 1993, Perez et al 1996, Clarke 1997, Mackintosh et al 2007, Balseiro et al 2008). In our opinion, that infection pressure, strain type and epidemiological story of the herd are the most important factors in the severity of the lesions.

In this report Map-positive cultures plus the PCR IS901 negative results in all animals, clearly show that the histopathological findings are due to Map infection only. However, some authors have described Maa-Map co-infection with indistinguishable clinical and pathological lesions (Mackintosh et al 2004, Machackova-Kopecna et al 2005, Glawischnig et al 2006). The present results show a reliable technique that combined with tools such as culture, help to obtain a correct diagnosis. Additionally, the results obtained from formalin fixed paraffin embedded tissues allowed performing retrospective studies to determine coinfection, even when fresh feaces or tissues were not available for culture.

The occurrence of Map-infected deer found in this area suggests a potential transmission of Map from livestock through the faecal-oral route. Since a clinically affected cow may shed over $10^{8}$ bacteria per gram of faeces (Whittington et al 2000), and an infective dose is considered to be $10^{6}$, the likelihood of transmission to freeranging immature ruminants, sharing pasture directly or indirectly with infected cattle is high. Epidemiological evidence that should be addressed is the fact that the deer herd is located in the proximity of a dairy farm that has more than 800 lactating cows and both farms belongs to the same owner. Furthermore, biosecurity management measures were violated, because the same workers participate in both farms and herds, vehicles transit without any disinfection from cattle to deer farm. Additionally, other evidence that confirms that cattle and deer populations are connected is the fact that molecular typing strategies used to characterize Map isolated from deer lack of variation between cattle control strain. The latter could be indicative that both species shares the same bacteria

Table 2. MIRU-VNTR results in two deer isolates and control strain.

Resultados de MIRU-VNTR en dos de las cepas aisladas de ciervo y cepa control.

\begin{tabular}{lccccccccc}
\hline Strain & \multicolumn{7}{c}{ Number of repeats } \\
\hline & locus1 & locus2 & locus3 & locus4 & locus5 & locus6 & locus7 & locus8 \\
TR292 & TRX3 & TR25 & TR47 & TR3 & TR7 & TR10 & TR32 & Host \\
\hline 1 & 4 & 2 & 3 & 3 & 2 & 2 & 2 & 2 & deer \\
2 & 4 & 2 & 3 & 3 & 2 & 2 & 2 & 2 & deer \\
K10 & 3 & 2 & 3 & 3 & 2 & 2 & 2 & 2 & ATCC control \\
\hline
\end{tabular}


and by this contribute with a piece of evidence to think of interspecies transmission.

We expected this dairy cattle herd to be infected with Map, since currently between 50 to $87 \%$ of dairy herds in Southern Chile are considered infected (Kruze et al 2013) and no control programs have been implemented neither at a national nor local level. The chance that Map remains in the environment and become a potential risk for susceptible host is high due to its ability to survive for long periods outside the hosts, enabling it to persist and spread in grasslands, and withstand a periodic lack of suitable hosts. The time required to eradicate the organism from the environment is unknown. It has been suggested that at least 6 months to a year is required to render pastures safe after being grazed by infected cattle (Lovell et al 1944). In this case, it could be concluded that pasture might be a source of infection, because they had been recently used to raise dairy cattle probably affected by paratuberculosis.

This first report of farmed deer affected by paratuberculosis in Chile is a starting point to determine the appropriate diagnostic tools for its recognition and differentiation between Map infection, Maa infection and coinfection with both subespecies. Although differentiation of avian tuberculosis and paratuberculosis is technically challenging, multiple diagnostic tools used together, plus detailed epidemiological study are advisable in order to reach a precise diagnosis of captive deer.

Furthermore, the study shows the effectiveness of the bacteria to infect susceptible populations, even when the animals are not in direct contact, reaffirming the bacteria's ability to remain and survive on soil. The studied deer herd becomes now a new Map infection focus to other domestic and wild animals in their surroundings. Finally, it is important to address the zoonotic potential of these bacteria, considering that it this farm produces venison for human consumption.

\section{REFERENCES}

Alvarez J, L De Juan, V Briones, B Romero, A Aranaz, JF Fernandez-Garayzabal, A Mateos. 2005. Mycobacterium avium subspecies paratuberculosis in fallow deer and wild boar in Spain. Vet Rec 156, 212-213.

Balseiro A, JF Garcia Marin, P Solano, JM Garrido, JM Prieto. 2008. Histopathological classification of lesions observed in natural cases of paratuberculosis in free-ranging fallow deer (Dama dama). J Comp Pathol 138, 180-188.

Buergelt CD, C Hall, K McEntee, JR Duncan. 1978. Pathological evaluation of paratuberculosis in naturally infected cattle. Vet Pathol 15, 196-207.

Campbell SG. 1995. The inconvenience of lymph node gross lesions (non-M. bovis) at post mortem inspection of deer. Proceedings of a Deer Course for Veterinarians, No. 12, Deer Branch of the New Zealand Veterinary Association, Pp 87-95.

Carrigan MJ, JT Seaman. 1990. The pathology of Johne's disease in sheep. Aust Vet J 67, 47-50.
Chiodini RJ, WM Chamberlin, J Sarosiek and RW McCallum. 2012. Crohn's disease and the mycobacterioses: a quarter century later. Causation or simple association? Crit Rev Microbiol 38, 52-93.

Clark RG, JF Griffin, CG Mackintosh. 2010. Johne's disease caused by Mycobacterium avium subsp. paratuberculosis infection in red deer (Cervus elaphus): an histopathological grading system, and comparison of paucibacillary and multibacillary disease. New Zeal Vet J 58, 90-97.

Clarke CJ, D Little. 1996. The pathology of ovine paratuberculosis: gross and histological changes in the intestine and other tissues. J Comp Pathol 114, 419-437.

Clarke CJ. 1997. The pathology and pathogenesis of paratuberculosis in ruminants and other species. J Comp Pathol 116, 217-261.

de Lisle GW, GF Yates, DM Collins. 1993. Paratuberculosis in farmed deer: case reports and DNA characterization of isolates of Mycobacterium paratuberculosis. J Vet Diagn Invest 5, 567-571.

de Lisle GW, GF Yates, H Montgomery. 2003. The emergence of Mycobacterium paratuberculosis in farmed deer in New Zealand - a review of 619 cases. New Zeal Vet J 51, 58-62.

Del-Pozo J, S Girling, J McLuckie, E Abbondatix, K Stevenson. 2013. An unusual presentation of Mycobacterium avium spp. paratuberculosis infection in a captive tundra reindeer (Rangifer tarandus tarandus). J Comp Path 149, 126-131.

Fawcett AR, PJ Goddard, WA McKelvey, D Buxton, HW Reid, A Greig, AJ Macdonald. 1995. Johne's disease in a herd of farmed red deer. Vet Rec 136, 165-169.

Glawischnig W, T Steineck, J Spergser. 2006. Infections caused by Mycobacterium avium subspecies avium, hominissuis, and paratuberculosis in free-ranging red deer (Cervus elaphus hippelaphus) in Austria, 2001-2004. J Wildl Dis 42, 724-731.

Godfroid J, F Boelaert, A Heier, C Clavareau, V Wellemans, M Desmecht, S Roels, K Walravens. 2000. First evidence of Johne's disease in farmed red deer (Cervus elaphus) in Belgium. Vet Microbiol 77, 283-290.

Godfroid J, C Delcorps, LM Irenge, K Walravens, S Marche, JL Gala. 2005. Definitive differentiation between single and mixed mycobacterial infections in red deer (Cervus elaphus) by a combination of duplex amplification of p34 and $f 57$ sequences and Hpy188I enzymatic restriction of duplex amplicons. J Clin Microbiol 43, 4640-4648.

Gonzalez J, MV Geijo, C Garcia-Pariente, A Verna, JM Corpa, LE Reyes, MC Ferreras, RA Juste, JF Garcia Marin, V Perez. 2005. Histopathological classification of lesions associated with natural paratuberculosis infection in cattle. J Comp Pathol 133, 184-196.

Grinbers J, I Caorsi. 1958. Enfermedad de Johne o Paratuberculosis en Chile. Publicaciones Científicas de la Universidad Austral de Chile 4, 9-13.

Huda A, HE Jensen. 2003. Comparison of histopathology, cultivation of tissues and rectal contents, and interferongamma and serum antibody responses for the diagnosis of bovine paratuberculosis. J Comp Pathol 129, 259-267.

Kruze J, M Salgado, E Paredes, A Mella, MT Collins. 2006. Goat paratuberculosis in Chile: first isolation and confirmation of Mycobacterium avium subspecies paratuber- 
culosis infection in a dairy goat. J Vet Diagn Invest 18 , 476-479.

Kruze J, G Monti, F Schulze, A Mella, S Leiva. 2013. Herd-level prevalence of Map infection in dairy herds of southern Chile determined by culture of environmental fecal samples and bulk-tank milk qPCR. Prev Vet Med 111, 319-324.

Lombard JE. 2011. Epidemiology and economics of paratuberculosis. Vet Clin North Am Food Anim Pract 27, 525-535.

Lovell R, M Levi, J Francis. 1944. Studies on the survival of Johne's bacilli. J Comp Pathol 154, 120-129.

Machackova-Kopecna M, M Bartos, M Straka, V Ludvik, P Svastova, J Alvarez, J Lamka, I Trcka, F Treml, I Parmova, I Pavlik. 2005. Paratuberculosis and avian tuberculosis infections in one red deer farm studied by IS900 and IS901 RFLP analysis. Vet Microbiol 105, 261-268.

Mackintosh CG, J Webster, I Corson, B Masters, AJ Pearse and R Littlejohn. 1997. Outbreak of avian tuberculosis in red deer. Proceedings of a Deer Course for Veterinarians, Deer Branch of the New Zealand Veterinary Association, Pp 243-250.

Mackintosh CG, JC Haigh, JF Griffin. 2002. Bacterial diseases of farmed deer and bison. Rev Sci Tech 21, 249-263.

Mackintosh CG, GW de Lisle, DM Collins, JF Griffin. 2004. Mycobacterial diseases of deer. New Zeal Vet J 52, 163174.

Mackintosh CG, RE Labes, RG Clark, GW de Lisle, JF Griffin. 2007. Experimental infections in young red deer (Cervus elaphus) with a bovine and an ovine strain of Mycobacterium avium subsp paratuberculosis. New Zeal Vet J 55, 23-29.

Manning EJ, H Steinberg, K Rossow, GR Ruth, MT Collins. 1998. Epizootic of paratuberculosis in farmed elk. J Am Vet Med Assoc 213, 1320-1322.

Marco I, M Ruiz, R Juste, JM Garrido, S Lavin. 2002. Paratuberculosis In Free-Ranging Fallow Deer In Spain. $J$ Wildl Dis 38, 629-632.

Marsh I, R Whittington, D Cousins. 1999. PCR-restriction endonuclease analysis for identification and strain typing of Mycobacterium avium subsp. paratuberculosis and Mycobacterium avium subsp. avium based on polymorphisms in IS1311. Mol Cell Probes 13, 115-126.

Mereb GC, DO Bedotti, VH Suarez, MR Busetti, AR Moreira, RM Lorenzo. 1994. Paratuberculosis in red deer. Veterinaria Argentina 11, 107-12.

Miller J, A Jenny, J Rhyan, D Saari, D Suarez. 1997. Detection of Mycobacterium bovis in formalin-fixed, paraffinembedded tissues of cattle and elk by PCR amplification of an IS6110 sequence specific for Mycobacterium tuber- culosis complex organisms. J Vet Diagn Invest 9, 244-249.

Paolicchi FA, A Vagnozz, CG Morsella, AE Verna, AR Massone, EL Portiansky, EJ Gimeno. 2001. Paratuberculosis in red deer (Cervus elaphus): an immunohistochemical study. $J$ Vet Med B 48, 313-320.

Perez V, JF Garcia Marin, JJ Badiola. 1996. Description and classification of different types of lesion associated with natural paratuberculosis infection in sheep. J Comp Pathol $114,107-122$.

Power SB, J Haagsma, DP Smyth. 1993. Paratuberculosis in farmed red deer (Cervus elaphus) in Ireland. Vet Rec 132, 213-216.

Salgado M, D Herthnek, G Bolske, S Leiva, J Kruze. 2009. First isolation of Mycobacterium avium subsp. Paratuberculosis from wild guanacos (Lama guanicoe) on Tierra del Fuego Island. J Wildl Dis 45, 295-301.

Salgado M, MT Collins, F Salazar, J Kruze, G Bolske, R Soderlund, R Juste, IA Sevilla, F Biet, F Troncoso, M Alfaro. 2011 ${ }^{\text {a }}$. Fate of Mycobacterium avium subsp. paratuberculosis after application of contaminated dairy cattle manure to agricultural soils. Appl Environ Microbiol 77, 2122-2129.

Salgado M, EJ Manning, G Monti, G Bolske, R Soderlund, M Ruiz, E Paredes, S Leiva, H Van Kruningen, J Kruze. $2011^{\mathrm{b}}$. European hares in Chile: a different lagomorph reservoir for Mycobacterium avium subsp. paratuberculosis? J Wildl Dis 47, 734-738.

Thibault VC, M Grayon, ML Boschiroli, C Hubbans, P Overduin, K Stevenson, M.C Gutierrez, P Supply, F Biet. 2007. New variable-number tandem-repeat markers for typing Mycobacterium avium subsp. paratuberculosis and $M$. avium strains: comparison with IS900 and IS1245 restriction fragment length polymorphism typing. J Clin Microbiol 45, 2404-2410.

van Kooten HC, CG Mackintosh, AP Koets. 2006. Intra-uterine transmission of paratuberculosis (Johne's disease) in farmed red deer. New Zeal Vet J 54, 16-20.

Whittington R, I Marsh, E Choy, D Cousins. 1998. Polymorphisms in IS1311, an insertion sequence common to Mycobacterium avium and M. avium subsp. paratuberculosis, can be used to distinguish between and within these species. Mol Cell Probes 12, 349-358.

Whittington RJ, LA Reddacliff, I Marsh, S McAllister, V Saunders. 2000. Temporal patterns and quantification of excretion of Mycobacterium avium subsp. paratuberculosis in sheep with Johne's disease. Aust Vet J 78, 34-37.

Zamora J, J Kruze, C Schifferli. 1975. Ovine paratuberculosis: first case reported in Chile. Arch Med Vet 7, 15-17. 